\title{
Effects of age and time of day of sampling on proximate and fatty acid composition of whole eggs from two strains of laying hens
}

\author{
N. Stanišić ${ }^{1}$, V. Petričević ${ }^{1}$, Z. Škrbić ${ }^{1}$, M. Lukić ${ }^{1}$, Z. Pavlovski ${ }^{1}$, S. Lilić ${ }^{2}$, and M. Petričević1 \\ ${ }^{1}$ Institute for Animal Husbandry, Belgrade-Zemun, Republic of Serbia \\ ${ }^{2}$ Institute of Meat Hygiene and Technology, Belgrade, Republic of Serbia \\ Correspondence to: N. Stanišić (nikola0135@yahoo.com)
}

Received: 5 November 2014 - Accepted: 26 March 2015 - Published: 23 April 2015

\begin{abstract}
The aim of the present study was to determine the effects of breed (Naked Neck - NN - and Lohmann Brown - LB), age (46 to 49 weeks) and the time of day of sampling (morning eggs - M - and afternoon eggs A) on the proximate and fatty acid composition of whole eggs.

Eggs of commercial hens (LB) had significantly $(P<0.001)$ less fat, ash and protein and lower dry-matter content (more water content) compared to the autochthonous breed (NN). The NN eggs contained significantly $(P<0.001)$ more SFA (saturated fatty acid) and less PUFA (polyunsaturated fatty acid) than LB ones, while the share of the eggs' total $\mathrm{n}-3$ fatty acids did not differ significantly between breeds. The share of total MUFA (monounsaturated fatty acid) significantly $(P=0.011)$ decreased, while the share of total PUFA, $\mathrm{n}-6$ and $\mathrm{n}-6 / \mathrm{n}$ 3 ratio significantly increased ( $P<0.001 ; P<0.001 ; P=0.032$, respectively) with age of hens. Additionally, compared with morning eggs, afternoon eggs had a significantly $(P=0.046)$ higher share of total $\mathrm{n}-6$ fatty acids.

PCA (principal component analysis) offered a good separation of the samples according to breed and age when two first principal component were extracted. $\mathrm{PC} 1$ was positively related to parameters of proximate composition and SFA content, while PC2 was positively determined by PUFA, $n-6$ and $n-3$ content. Eggs of autochthonous hens (NN) were located in the positive area of PC1, whereas those from the commercial hens (LB) were in the negative quarter, which indicates opposite characteristics.
\end{abstract}

\section{Introduction}

Potential health benefits attributed to eggs are mostly determined by the share of unsaturated fatty acids. Nowadays, the poultry industry is geared towards increasing the unsaturated fatty acid content of chicken eggs (Farrell, 1998), particularly n-3 fatty acids, given their beneficial effects on human health, cardiovascular diseases, some autoimmune disorders, diabetes and also some types of cancer (Wesley Alexander, 1998; Aronson et al., 2001). Several factors affect the egg composition and lipid profile, but the most important one is a hen's diet (Milinsk et al., 2003). Nonetheless, the fatty acid profile of eggs is also dependent on the hen's age, strain and breed (Edwards, 1964; Nielsen, 1998; Scheideler et al., 1998).
Many studies have investigated the fatty acid composition of the eggs of commercial layers reared in commercial production system (Guardiola et al., 1994; Lopez-Bote et al., 1998; Nielsen, 1998), which include confinement facilities, highly productive hybrid layers kept in limited space (mostly in battery cages) and intensive feeding (Rakonjac et al., 2014). All of these factors have contributed to battery farming becoming the most common table egg production system in the world. However, more recently, the development of consumer awareness regarding animal welfare has led to the introduction of alternative laying hen rearing systems, such as the free-range production system (Škrbić et al., 2010).

In the Republic of Serbia, the preservation of autochthonous poultry breeds is of national interest as part of 
the government strategy in order to contribute to the economic development of certain rural areas (Rodić et al., 2010). Naked Neck is Serbian autochthonous hen breed. It is commonly reared in rural households and in small flocks. It has lower production characteristics but is highly resistant and low-maintenance with regard to rearing and nutrition. The main characteristics of this hen breed have been described in studies by Pavlovski et al. (2009) and Milošević et al. (2013).

The aim of the present study was to determine differences in the proximate and fatty acid composition of whole eggs between the Naked Neck (NN) and the Lohmann Brown (LB) hen breed. This research considered different ages of hens and different egg sampling times during the day (currently no data is available on the differences in egg lipid profile between morning and afternoon eggs). Naked Neck was selected as an autochthonous Serbian hen breed, while Lohmann Brown was chosen as the most common commercial hen breed in Serbia.

\section{Material and methods}

\subsection{Experimental design and animal management}

The experiment was conducted at the Institute for Animal Husbandry (Belgrade, Republic of Serbia). Two hen flocks (Naked Neck and Lohmann Brown) were reared in a freerange production system. The trial involved 40 chickens per group. The diet consisted of a complete commercial feeding mixture for laying hens (Table 1) in addition to various cereals and grazing. All hens were fed ad libitum and had free access to water. The complete production procedure was described in the work of Škrbić et al. (2010). Briefly, after 3 weeks in an intensive fattening system, hens were fattened extensively on an unlimited source (pasture) from early March to mid-November. Feed contained no animal products, feed products produced from genetically modified organisms or growth stimulators but did contain a limited number of additives.

All hens were 46 weeks of age at the beginning of the trial. The experiment lasted 3 weeks. The random sampling of eggs was performed at the beginning (46 weeks of age group A) and after every week for 3 weeks (groups B, C and D). On every sampling day six eggs were collected in the morning ( $\mathrm{M}$ - around 08:00 local time) and six in the afternoon (A - around 16:00 local time).

After sampling, each egg was broken and the yolk and white were mixed, sealed in plastic bags under vacuum and stored at $-20^{\circ} \mathrm{C}$ until analysis. The analyses started when all the samples had been collected.

\subsection{Determination of proximate composition}

The proximate composition of eggs was determined in the following manner: dry-matter content was determined by drying samples at $103 \pm 2{ }^{\circ} \mathrm{C}$ (ISO 1442,1997$)$; protein con-
Table 1. Composition of feed of complete commercial feeding mixture for laying hens.

\begin{tabular}{lr}
\hline Item & Amount \\
\hline Ingredient $\left(\mathrm{g} \mathrm{kg}^{-1}\right)$ & \\
\hline Corn & 600.0 \\
Soybean meal & 200.0 \\
Sunflower meal & 80.0 \\
Monocalcium phosphate & 10.0 \\
Chalk (granules) & 80.0 \\
Chalk (powder) & 20.0 \\
Salt & 3.0 \\
Zeolite clay "Mikozel" & 2.0 \\
Premix & 5.0 \\
\hline Chemical composition & \\
\hline Crude protein $\left(\mathrm{g} \mathrm{kg}^{-1}\right)$ & 155.0 \\
Calcium (g kg-1) & 40.0 \\
Phosphorus $\left(\mathrm{g} \mathrm{kg}^{-1}\right)$ & 3.2 \\
Metabolizable energy (kcal kg & 2788.0 \\
\hline
\end{tabular}

tent was determined by the Kjeldahl method, i.e., by multiplying by the nitrogen with a factor of 6.25 (ISO 937, 1978); total fat content was determined by the Soxhlet method (ISO 1443, 1973); and ash content was determined by the mineralization of samples at $550 \pm 25^{\circ} \mathrm{C}$ (ISO 936, 1998).

\subsection{Extraction of lipids}

In order to determine fatty acids, all lipids were extracted from whole eggs by accelerated solvent extraction (ASE 200, Dionex, Sunnyvale, CA). The extraction was done after mixing eggs with diatomaceous earth and with a mixture of $n$ hexane and isopropanol $(60: 40 \mathrm{v} / \mathrm{v})$ in a $33 \mathrm{~mL}$ extraction cell at $100^{\circ} \mathrm{C}$ and a nitrogen pressure of $10.3 \mathrm{MPa}$; following this, the solvent was removed under a stream of nitrogen in a Dionex Solvent Evaporator 500 at $50^{\circ} \mathrm{C}$ until dryness. Fat extract was further used for fatty acid determination.

\subsection{Fatty acid analysis}

Fatty acid methyl esters (FAMEs) were prepared by transesterification by using trimethylsulfonium hydroxide, according to the ISO 5509 (2007) procedure. For FAME analyses a GC (gas chromatograph) Shimadzu 2010 (Kyoto, Japan) was used, equipped with a split/splitless injector, fused silica cyanopropyl HP-88 column $(100 \mathrm{~m} \times 0.25 \mathrm{~mm} \times 0.20 \mu \mathrm{m}$, $\mathrm{J} \& \mathrm{~W}$ Scientific, USA) and flame ionization detector. The injector temperature was $250^{\circ} \mathrm{C}$ and the detector temperature was $280^{\circ} \mathrm{C}$. The carrier gas was nitrogen at a flow rate of $1.33 \mathrm{~mL} \mathrm{~min}^{-1}$ and with an injector split ratio of $1: 50$. The injected volume was $1 \mu \mathrm{L}$. Chromatographic peaks in the samples were identified by comparing relative retention times of FAME peaks with peaks in a Supelco 37 Compo- 
Table 2. Effect of breed, age and time of sampling on proximate composition of whole eggs (least square means).

\begin{tabular}{lrrr|rrrrr|r|rr}
\hline$\%$ & \multicolumn{3}{c|}{ Breed $^{1}$} & \multicolumn{5}{c|}{ Age $^{2}$} & \multicolumn{3}{c}{ Time of day $^{3}$} \\
\cline { 2 - 12 } & NN & LB & SEM $^{4}$ & A & B & C & D & SEM & M & A & SEM \\
\hline Dry matter & $26.50^{\mathrm{a}}$ & $21.47^{\mathrm{b}}$ & 0.24 & 24.70 & 25.26 & 24.57 & 24.88 & 0.27 & 24.93 & 24.78 & 0.19 \\
Fat & $11.39^{\mathrm{a}}$ & $7.19^{\mathrm{b}}$ & 0.24 & $9.63^{\mathrm{a}}$ & $10.51^{\mathrm{b}}$ & $9.99^{\mathrm{ab}}$ & $9.67^{\mathrm{a}}$ & 0.27 & 9.91 & 9.99 & 0.19 \\
Ash & $0.95^{\mathrm{a}}$ & $0.89^{\mathrm{b}}$ & 0.01 & 0.92 & 0.94 & 0.92 & 0.95 & 0.01 & 0.93 & 0.94 & 0.01 \\
Protein & $14.56^{\mathrm{a}}$ & $13.37^{\mathrm{b}}$ & 0.14 & 14.14 & 14.06 & 13.93 & 14.25 & 0.16 & 14.07 & 14.10 & 0.11 \\
\hline
\end{tabular}

${ }^{1} \mathrm{NN}$ - Naked Neck; LB - Lohmann Brown. ${ }^{2} \mathrm{~A}$ - at the beginning of trial; B - after 1 week; C - after 2 weeks; D - after 3 weeks. ${ }^{3} \mathrm{M}$ - morning; A - afternoon. ${ }^{4}$ SEM - standard error of mean. ${ }^{a-b}$ Different letters within the same row denote significant differences between means.

Table 3. $t$ test and analysis of variance regarding the effect of breed, age and time of day on proximate composition ( $P$ values of independent variables and interactions).

\begin{tabular}{lccccccc}
\hline & Breed (B) & Age (A) & Time of day $(\mathrm{T})$ & $\mathrm{B} \times \mathrm{A}$ & $\mathrm{A} \times \mathrm{T}$ & $\mathrm{B} \times \mathrm{T}$ & $\mathrm{B} \times \mathrm{A} \times \mathrm{T}$ \\
\hline Dry matter & $<0.001$ & 0.316 & 0.578 & 0.513 & 0.985 & 0.800 & 0.088 \\
Fat & $<0.001$ & 0.041 & 0.771 & 0.812 & 0.410 & 0.438 & 0.122 \\
Ash & $<0.001$ & 0.096 & 0.532 & 0.240 & 0.435 & 0.029 & 0.094 \\
Protein & $<0.001$ & 0.549 & 0.810 & 0.380 & 0.104 & 0.665 & 0.069 \\
\hline
\end{tabular}

nent FAME mix standard (Supelco, Bellefonte, USA), and the results are expressed as a percentage of total fatty acids.

\subsection{Statistical analysis}

An analysis of variance (ANOVA) using the general linear model (GLM) procedure of the IBM SPSS Statistics 20 software (SPSS, 2010) was performed for all variables considered. If the effect of the main factor (age) was found to be significant, a $t$ test was used to evaluate the significance of difference at $P<0.05$. Principal component analysis (PCA) was used to determine the relationships between eggs of different breeds (NN and LB), different ages (A, B, C and D) and different times of sampling ( $\mathrm{M}$ and $\mathrm{A}$ ) and the data related to proximate composition and fatty acid parameters. PCA was done with the abovementioned statistical software package, using the dimension reduction technique, where the extraction method was principal component analysis and the rotation method was the direct oblimin one.

All data in Tables 2 and 4 contain the least squares means (LSMs) and standard errors of the LSMs (SEMs). In Tables 3 and 5, all levels of significant are shown ( $P$ values).

\section{Results}

\subsection{Proximate composition of eggs}

The proximate composition of whole eggs differs significantly between the hen breeds (Tables 2 and 3). Eggs from commercial hens had significantly less fat, ash and protein and more water content (lower dry-matter content) compared with those from the autochthonous hen breed $(P<0.001)$.
Age significantly influenced fat content $(P=0.041)$; it was determined that the eggs in the B group had significantly more fat compared with group A and D eggs. The age of hens and the time of egg sampling did not have a significant effect on the proximate composition of the examined eggs (Tables 2 and 3), but the interaction between breed and time of day $(B \times T)$ was significant for ash content $(P=0.029)$.

\subsection{Fatty acid profile of eggs}

The hen breed had a significant effect on the fatty acid composition of whole eggs (Tables 4 and 5). The eggs of NN hens contained significantly more SFA (saturated fatty acid) than LB eggs. These differences are due to a higher myristic $(\mathrm{C} 14: 0, P=0.021)$, pentadecanoic $(\mathrm{C} 15: 0, P=0.047)$ and palmitic acid $(\mathrm{C} 16: 0, P<0.001)$ content, even though LB eggs had a higher margaric $(\mathrm{C} 17: 0, P=0.014)$ and stearic acid $(\mathrm{C} 18: 0, P<0.001)$ content. The higher total MUFA (monounsaturated fatty acid; $P=0.020$ ) content was determined in NN eggs, with a higher palmitoleic (C16:1, $P<0.001)$ and eicosenoic acid $(\mathrm{C} 20: 1, P<0.001)$ content. The eggs of LB hens contained significantly more total PUFA (polyunsaturated fatty acid) and $\mathrm{n}-6$ fatty acids compared to NN hens $(P<0.001)$. These differences are due to a higher linoleic $(\mathrm{C} 18: 2 \mathrm{n}-6, P<0.001)$, arachidonic $(\mathrm{C} 20: 4 \mathrm{n}-6$, $P=0.003)$ and docosahexaenoic acid (DHA, C22:6 n-3, $P<0.001)$ content, which also led to a higher $\mathrm{n}-6 / \mathrm{n}-3$ ratio $(P=0.002)$.

The share of some fatty acids significantly changed as the age of hens increased (Tables 4 and 5). Despite the significant impact on the individual SFAs (increase in the share of pentadecanoic $(\mathrm{C} 15: 0, P=0.044)$ and margaric acids $(\mathrm{C} 17: 0$, 
Table 4. Effect of breed, age and time of sampling on fatty acid composition of whole eggs (least square means).

\begin{tabular}{|c|c|c|c|c|c|c|c|c|c|c|c|}
\hline & \multicolumn{3}{|c|}{ Breed $^{1}$} & \multicolumn{5}{|c|}{$\mathrm{Age}^{2}$} & \multicolumn{3}{|c|}{ Time of day ${ }^{3}$} \\
\hline & $\mathrm{NN}$ & LB & SEM $^{4}$ & A & $\mathrm{B}$ & $\mathrm{C}$ & $\mathrm{D}$ & SEM & M & A & SEM \\
\hline $14: 0$ & $0.24^{\mathrm{a}}$ & $0.21^{\mathrm{b}}$ & 0.01 & 0.24 & 0.23 & 0.23 & 0.23 & 0.01 & 0.23 & 0.23 & 0.00 \\
\hline $15: 0$ & $0.05^{\mathrm{a}}$ & $0.04^{\mathrm{b}}$ & 0.01 & $0.03^{\mathrm{a}}$ & $0.04^{\mathrm{a}}$ & $0.05^{\mathrm{b}}$ & $0.06^{\mathrm{c}}$ & 0.01 & $0.04^{\mathrm{a}}$ & $0.06^{\mathrm{b}}$ & 0.01 \\
\hline $16: 0$ & $26.51^{\mathrm{a}}$ & $21.52^{\mathrm{b}}$ & 0.14 & 24.69 & 24.80 & 24.73 & 24.97 & 0.17 & 24.83 & 24.77 & 0.12 \\
\hline $16: 1$ & $2.62^{\mathrm{a}}$ & $1.40^{\mathrm{b}}$ & 0.02 & $2.28^{\mathrm{a}}$ & $2.32^{\mathrm{a}}$ & $2.20^{\mathrm{b}}$ & $2.04^{\mathrm{c}}$ & 0.02 & 2.22 & 2.24 & 0.02 \\
\hline $17: 0$ & $0.13^{\mathrm{a}}$ & $0.19^{\mathrm{b}}$ & 0.00 & $0.14^{\mathrm{a}}$ & $0.17^{\mathrm{b}}$ & $0.15^{\mathrm{ab}}$ & $0.16^{\mathrm{b}}$ & 0.00 & 0.15 & 0.16 & 0.00 \\
\hline $18: 0$ & $8.05^{\mathrm{a}}$ & $10.24^{b}$ & 0.04 & $9.07^{\mathrm{a}}$ & $8.68^{b}$ & $8.60^{b}$ & $9.32^{\mathrm{c}}$ & 0.05 & $9.00^{\mathrm{a}}$ & $8.83^{b}$ & 0.03 \\
\hline $18: 1 n-9$ & 41.80 & 41.86 & 0.16 & $42.28^{\mathrm{a}}$ & $41.69^{b}$ & $41.52^{b}$ & $40.07^{\mathrm{c}}$ & 0.19 & 41.56 & 41.23 & 0.13 \\
\hline $18: 2 n-6$ & $16.79^{\mathrm{a}}$ & $20.35^{\mathrm{b}}$ & 0.11 & $17.06^{\mathrm{a}}$ & $17.75^{b}$ & $19.34^{\mathrm{c}}$ & $19.62^{c}$ & 0.12 & $18.10^{\mathrm{a}}$ & $18.78^{b}$ & 0.09 \\
\hline $18: 3 n-3$ & $0.76^{\mathrm{a}}$ & $0.54^{\mathrm{b}}$ & 0.02 & $0.73^{\mathrm{a}}$ & $0.75^{\mathrm{a}}$ & $0.73^{\mathrm{a}}$ & $0.68^{\mathrm{b}}$ & 0.03 & 0.72 & 0.74 & 0.02 \\
\hline $18: 3 n-6$ & 0.07 & 0.07 & 0.01 & $0.06^{\mathrm{a}}$ & $0.07^{\mathrm{ab}}$ & $0.09^{b}$ & $0.08^{\mathrm{b}}$ & 0.01 & 0.07 & 0.08 & 0.01 \\
\hline $20: 1$ & $0.25^{\mathrm{a}}$ & $0.14^{\mathrm{b}}$ & 0.01 & $0.26^{\mathrm{a}}$ & $0.21^{\mathrm{b}}$ & $0.15^{\mathrm{c}}$ & $0.20^{\mathrm{b}}$ & 0.01 & 0.21 & 0.22 & 0.00 \\
\hline $20: 2$ & 0.26 & 0.27 & 0.01 & $0.23^{\mathrm{a}}$ & $0.25^{\mathrm{b}}$ & $0.29^{c}$ & $0.29^{c}$ & 0.01 & 0.27 & 0.26 & 0.01 \\
\hline $20: 3 n-6$ & 0.58 & 0.60 & 0.03 & $0.50^{\mathrm{a}}$ & $0.64^{\mathrm{b}}$ & $0.71^{\mathrm{c}}$ & $0.54^{\mathrm{d}}$ & 0.01 & 0.61 & 0.59 & 0.02 \\
\hline $20: 4 n-6$ & $1.47^{\mathrm{a}}$ & $1.75^{\mathrm{b}}$ & 0.03 & $1.52^{\mathrm{a}}$ & $1.56^{\mathrm{b}}$ & $1.55^{\mathrm{b}}$ & $1.66^{\mathrm{c}}$ & 0.02 & $1.61^{\mathrm{a}}$ & $1.53^{\mathrm{b}}$ & 0.01 \\
\hline $22: 6 n-3$ & $0.81^{\mathrm{a}}$ & $1.04^{\mathrm{b}}$ & 0.02 & $0.85^{\mathrm{a}}$ & $0.90^{\mathrm{b}}$ & $0.88^{\mathrm{b}}$ & $0.89^{\mathrm{b}}$ & 0.02 & 0.84 & 0.86 & 0.02 \\
\hline \multicolumn{12}{|l|}{ Total } \\
\hline SFA & $34.91^{\mathrm{a}}$ & $31.99^{\mathrm{b}}$ & 0.11 & $34.11^{\mathrm{ab}}$ & $33.91^{\mathrm{a}}$ & $33.77^{\mathrm{a}}$ & $34.72^{\mathrm{b}}$ & 0.14 & 34.23 & 34.06 & 0.09 \\
\hline MUFA & $44.31^{\mathrm{a}}$ & $43.34^{\mathrm{b}}$ & 0.11 & $44.83^{\mathrm{a}}$ & $44.20^{\mathrm{a}}$ & $43.85^{\mathrm{b}}$ & $42.33^{c}$ & 0.16 & 43.98 & 43.67 & 0.15 \\
\hline PUFA & $20.68^{a}$ & $24.58^{\mathrm{b}}$ & 0.09 & $20.95^{\mathrm{a}}$ & $21.90^{\mathrm{b}}$ & $23.37^{\mathrm{c}}$ & $23.77^{\mathrm{c}}$ & 0.10 & 22.44 & 22.80 & 0.10 \\
\hline$n-6$ & $17.74^{\mathrm{a}}$ & $21.21^{\mathrm{b}}$ & 0.09 & $19.83^{\mathrm{a}}$ & $20.05^{\mathrm{b}}$ & $21.70^{\mathrm{c}}$ & $21.87^{\mathrm{c}}$ & 0.10 & $20.40^{\mathrm{a}}$ & $20.95^{\mathrm{b}}$ & 0.06 \\
\hline$n-3$ & 1.60 & 1.59 & 0.01 & $1.58^{\mathrm{ab}}$ & $1.65^{\mathrm{c}}$ & $1.60^{\mathrm{a}}$ & $1.56^{\mathrm{b}}$ & 0.03 & 1.55 & 1.59 & 0.04 \\
\hline$n-6 / n-3$ & $11.10^{\mathrm{a}}$ & $13.34^{\mathrm{b}}$ & 0.05 & $12.53^{\mathrm{a}}$ & $12.17^{b}$ & $13.53^{\mathrm{a}}$ & $14.00^{c}$ & 0.06 & 13.16 & 13.10 & 0.05 \\
\hline
\end{tabular}

${ }^{1} \mathrm{NN}$ - Naked Neck; LB - Lohmann Brown. ${ }^{2} \mathrm{~A}$ - at the beginning of trial; B - after 1 week; C - after 2 weeks; D - after 3 weeks. ${ }^{3} \mathrm{M}-$ morning; A afternoon. ${ }^{4}$ SEM - standard error of mean. ${ }^{\mathrm{a}-\mathrm{d}}$ Different letters within the same row denote significant differences between means. PUFA stands for polyunsaturated fatty acid. MUFA stands for monounsaturated fatty acid. SFA stands for saturated fatty acid.

$P=0.019)$ ), the age of hens did not have a large impact on the share of total SFA of whole eggs $(P=0.047)$. On the other hand, the share of total MUFA significantly decreased $(P=0.011)$, while the share of total PUFA significantly increased $(P<0.001)$ with the age of hens. Hens from the $\mathrm{B}$ group had the significantly $(P=0.007)$ highest $n-3$ content compared with other groups. Age also had a significant effect on $n-6$ fatty acid content $(P=0.001)$; it was determined that they significantly increased with increasing age, which resulted in an increase in the $n-6 / n-3$ ratio $(P=0.032)$.

The time of sampling did not have a significant effect on the share of total SFA, PUFA or MUFA, but some differences between eggs collected in the morning and in the afternoon were established (Tables 4 and 5). This relates to the higher share of stearic (C18:0,P=0.003) and arachidonic acid (C20: $4 \mathrm{n}-6, P=0.006)$ and the lower share of pentadecanoic (C15:0, $P=0.002)$ and linoleic acid (C18:2 n-6, $P=0.009$ ) in morning eggs than those sampled in the afternoon. Additionally, afternoon eggs had a significantly higher share of total n-6 fatty acids $(P=0.046)$; however, this had no significant effect on differences in the n- $6 / n-3$ ratio between $\mathrm{M}$ and A eggs.
The three-factor analysis of variance showed that, in addition to the effects of the breed, age and time of day, the interaction of the main factors had a significant effect on the fatty acid composition of whole eggs (Table 5). The statistical analyses showed a significant effect of the interaction between breed and age $(\mathrm{B} \times \mathrm{A})$ for $\mathrm{C} 16: 0(P=0.019), \mathrm{C} 16: 1$ $(P=0.035)$, C18:2 n-6 $(P=0.009)$, C20:3 n-6 $(P=$ $0.023), \mathrm{C} 20: 4$ n-6 ( $P=0.016), \mathrm{C} 22: 6$ n-3 ( $P=0.002)$, total SFA $(P=0.023)$ and $n-6$ fatty acids $(P=0.011)$. The age and time of day interaction $(\mathrm{A} \times \mathrm{T})$ significantly affected the $\mathrm{C} 16: 1(P=0.048), \mathrm{C} 18: 3 \mathrm{n}-3(P=0.008)$ and $\mathrm{C} 20: 2$ $(P<0.001)$ content, while the breed and time of day interaction $(\mathrm{B} \times \mathrm{T})$ was significant for $\mathrm{C} 18: 2 \mathrm{n}-6(P=0.002)$, C22: 6 n-3 $(P=0.024)$, total SFA $(P=0.037)$ and n-6 fatty acid $(P=0.012)$. The interaction between all three main factors $(\mathrm{B} \times \mathrm{A} \times \mathrm{T})$ was significant for $\mathrm{C} 18: 2 \mathrm{n}-6(P=0.041)$, total SFA $(P=0.044)$ and PUFA $(P=0.021)$ content.

\subsection{Principal component analysis}

In order to differentiate between hen breed, age and egg sampling time, a PCA was performed, and the results are summarized in Table 6 and Fig. 1. Two factors were extracted. 
Table 5. $t$ test and analysis of variance of the effect of breed, age and time of day on fatty acid composition of whole eggs $(P$ values of independent variables and interactions).

\begin{tabular}{lrrccccc}
\hline & Breed (B) & Age (A) & Time of day (T) & B $\times$ A & A $\times$ T & B $\times$ T & B $\times$ A $\times$ T \\
\hline $14: 0$ & 0.021 & 0.598 & 0.638 & 0.332 & 0.144 & 0.098 & 0.105 \\
$15: 0$ & 0.047 & 0.044 & 0.002 & 0.437 & 0.888 & 0.324 & 0.271 \\
$16: 0$ & $<0.001$ & 0.638 & 0.688 & 0.019 & 0.100 & 0.202 & 0.114 \\
$16: 1$ & $<0.001$ & 0.004 & 0.371 & 0.035 & 0.048 & 0.643 & 0.577 \\
$17: 0$ & 0.014 & 0.019 & 0.333 & 0.203 & 0.557 & 0.256 & 0.349 \\
$18: 0$ & $<0.001$ & $<0.001$ & 0.003 & 0.122 & 0.066 & 0.411 & 0.210 \\
$18: 1 \mathrm{n}-9$ & 0.111 & 0.037 & 0.082 & 0.438 & 0.451 & 0.070 & 0.183 \\
$18: 2 \mathrm{n}-6$ & $<0.001$ & $<0.001$ & 0.009 & 0.009 & 0.203 & 0.002 & 0.041 \\
$18: 3 \mathrm{n}-3$ & $<0.001$ & 0.029 & 0.151 & 0.294 & 0.008 & 0.117 & 0.185 \\
$18: 3 \mathrm{n}-6$ & 0.486 & 0.024 & 0.466 & 0.139 & 1.746 & 0.225 & 0.070 \\
$20: 1$ & $<0.001$ & $<0.001$ & 0.228 & 0.214 & 0.052 & 0.790 & 0.355 \\
$20: 2$ & 0.305 & 0.008 & 0.109 & 0.091 & $<0.001$ & 0.252 & 0.114 \\
$20: 3 \mathrm{n}-6$ & 0.102 & $<0.001$ & 0.194 & 0.023 & 0.445 & 0.083 & 0.212 \\
$20: 4 \mathrm{n}-6$ & 0.003 & 0.009 & 0.006 & 0.016 & 0.605 & 0.138 & 0.205 \\
$22: 6 \mathrm{n}-3$ & $<0.001$ & 0.035 & 0.327 & 0.002 & 0.157 & 0.024 & 0.092 \\
\hline Total & & & & & & & \\
\hline SFA & $<0.001$ & 0.007 & 0.109 & 0.023 & 0.632 & 0.037 & 0.044 \\
MUFA & 0.020 & 0.011 & 0.163 & 0.344 & 0.244 & 0.150 & 0.113 \\
PUFA & $<0.001$ & $<0.001$ & 0.203 & 0.187 & 0.319 & 0.389 & 0.021 \\
$\mathrm{n}-6$ & $<0.001$ & 0.001 & 0.046 & 0.011 & 0.094 & 0.012 & 0.307 \\
$\mathrm{n}-3$ & 0.210 & 0.007 & 0.411 & 0.056 & 0.173 & 0.136 & 0.341 \\
$\mathrm{n}-6 / \mathrm{n}-3$ & 0.002 & 0.032 & 0.492 & 0.355 & 0.366 & 0.577 & 0.193 \\
\hline
\end{tabular}

Table 6. Factor loadings* for the rotated factor of the first two principal components obtained.

\begin{tabular}{lrrc}
\hline Compounds & PC1 & PC2 & Communality \\
\hline Dry matter (DM) & 0.926 & & 0.860 \\
Fat & 0.842 & & 0.733 \\
SFA & 0.829 & & 0.699 \\
Ash & 0.729 & & 0.609 \\
Protein & 0.570 & -0.445 & 0.444 \\
MUFA & & -0.884 & 0.784 \\
n-3 & & 0.778 & 0.679 \\
n-6 & -0.726 & 0.686 & 0.841 \\
PUFA & -0.692 & 0.777 & 0.915 \\
Eigenvalue & 4.587 & 1.977 & \\
Percent of variance & 50.97 & 21.96 & \\
Accumulative percentage & 50.97 & 72.93 & \\
\hline
\end{tabular}

* Loadings $<0.40$ are omitted.

Table 6 displays the items and factor loadings for the rotated factors, with loadings less than 0.40 omitted to improve clarity. The PCA showed that $72.93 \%$ of the variability was explained by two first principal components. Bartlett's test of sphericity for this model had a significance close to 0 , while the Kaiser-Meyer-Olkin measure was greater than 0.5, indicating that the correlations and variables were suitable for PCA.
Principal component 1 (PC1) accounted for $50.97 \%$ of the total variability, and it was the most important variable in terms of differences between eggs. As seen in Table 6, there are two groups of items that cluster, defined by high loadings. PC1 was positively related to parameters of proximate composition (dry matter, fat, ash and protein) and total SFA. This means that eggs with a higher fat content also had a higher SFA content because these parameters were clustered. Principal component 2 (PC2) accounted for $21.96 \%$ of the total variability and was positively determined by unsaturated fatty acids (PUFA, n-6 and n-3). Total MUFA content obtained negative loadings in $\mathrm{PC} 2$, showing a negative relationship with total PUFA, n- 6 and n-3 fatty acids. From the loadings of the variables involved in PC2, it seemed that those eggs with a greater PUFA content resulted in lower values for total MUFA.

The plot of the component loadings presented in Fig. 1a gives a visual representation of the loadings, plotted in space. This shows how closely related the items are to each other and to the components. Figure $1 \mathrm{~b}$ represents samples grouped according to the breed and age of hens, where different age periods are plotted as a function of breed. In Fig. $1 \mathrm{c}$, it can bee seen that the two first principal components did not distinguish the egg sampling time (M and $\mathrm{A}$ ) well, and, therefore, these parameters can not be differentiated by PCA. 
(a)

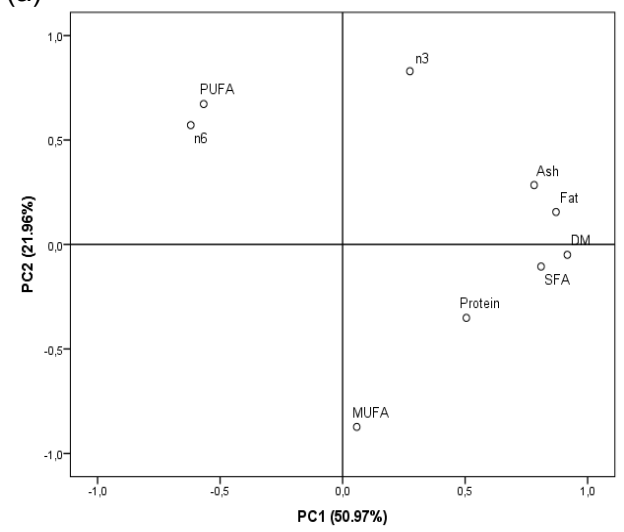

(b)

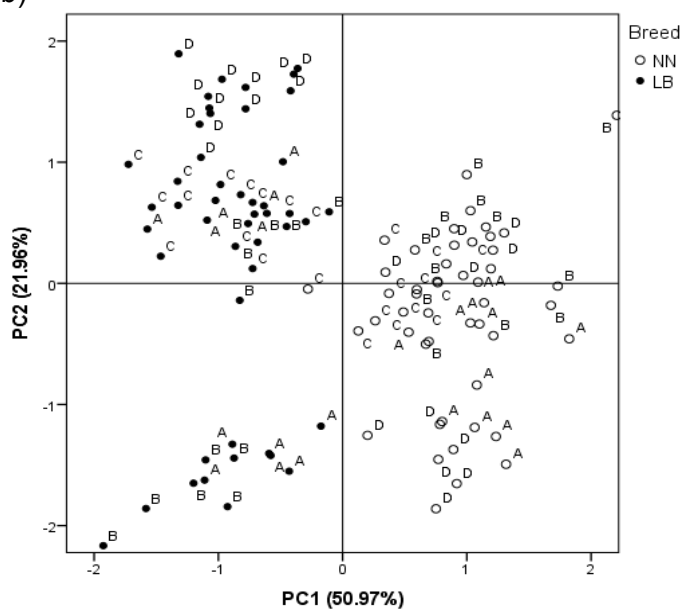

(c)

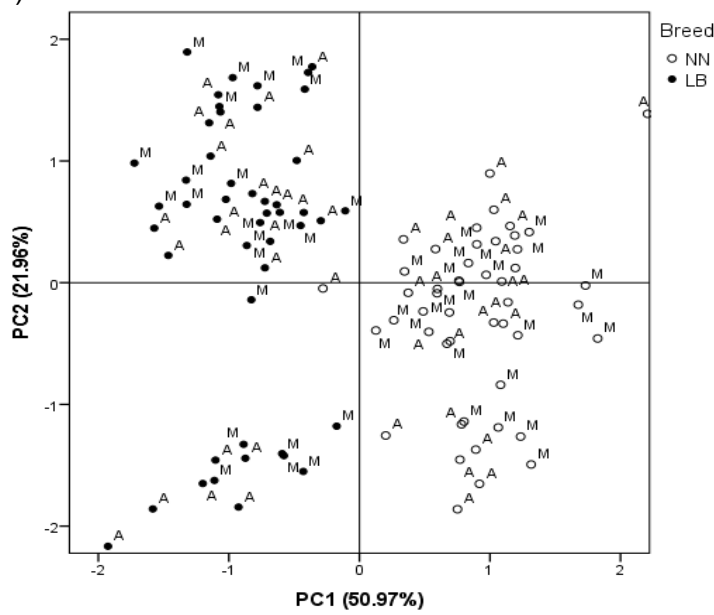

Figure 1. The plot of the component loadings of the whole eggs of three hen breeds. (a) Representation of the chemical variables as a function of both the first (PC1) and second (PC2) principal components; (b) samples grouped according to breed and age of hens vs. the first (PC1) and second (PC2) principal components; (c) samples grouped according to breed of hens and time of sampling of eggs vs. the first (PC1) and second (PC2) principal components.

\section{Discussion}

It is known that autochthonous animal breeds accumulate more fat in meat, milk or eggs, which could be the main reason for the higher fat and dry-matter contents determined in eggs from Naked Neck hens (Table 2). As noted by Rizzi and Chiericato (2010), it is possible that Lohmann Brown hens, which have favorable biological efficiency and a higher quantity of eggs compared to Naked Neck hens, have less lipid deposition in tissues and yolk, due to the factors mentioned. Similar findings were made by Anderson (2011). The lack of an effect of the age of hens on the proximate composition of eggs is in agreement with Nielsen (1998), who found no significant differences for dry-matter and lipid percentages in egg yolks between 21- and 56-week-old hens. However, Hammershøj (1995), analyzing a larger number of eggs (60 each from 30-, 34-, 38- and 42-week-old hens) established a very small decrease in dry matter in egg yolk with the age of the hen.

Generally, eggs from Naked Neck hens had a higher share of total SFA and MUFA and a lower share of total PUFA and n-6 fatty acid (Table 4). The results of SFA composition are contrast with the findings of Cherian et al. (1995) and Ayerza and Coates (2000), who found no differences in SFA yolks between brown and white hens. The absence of significant differences in the total n-3 fatty acid content between hen breeds is in agreement with the findings of Cherian et al. (1995) and Bean and Leeson (2003). Unlike these, Rizzi and Chiericato (2010) found differences in egg yolk n-3 fatty acids from four hen breeds. In the present trial, eggs of the commercial hen breed had a higher docosahexaenoic (C22: 6 $\mathrm{n}-3)$ and arachidonic acid (C20:4 n-6) content than those from the autochthonous breed, which is in disagreement with the findings of Ayerza and Coates (2000) and Bean and Leeson (2003).

Lin and Lee (1996) found that, in egg yolks of hens aged 39, 62 and 93 weeks, the long-chain PUFA content was higher in eggs laid by the younger hens, which contrasts with the results obtained in the present study (Table 4). Scheideler et al. (1998) reported that hens younger than 35 weeks deposited 25 to $50 \%$ less n-3 fatty acids in their eggs than did older birds. Similarly, in the present trial, there was a significant difference in the total $\mathrm{n}-3$ fatty acid content between the hens of different ages $(P=0.007)$. Regarding this, Scheideler et al. (1998) found that the deposition of $\alpha$-linolenic acid was greater at 58 weeks than at 36 weeks of age across all strains. A similar conclusion is drawn by Cherian (2008), who also found a very high positive correlation (0.91) between hen age and egg yolk $\alpha$-linolenic acid content. In contrast, Yilmaz-Dikmen and Sahan (2009) found that myristic and linoleic acid contents of yolk significantly decreased with increasing age of broilers $(P<0.01)$. An increase in the share of palmitoleic acid (C16:1) with the age of hens is found in the work of Latour et al. (1998), which contrasts with results from this trial. From a nutritional point of view, 
it is compelling that the share of arachidonic acid (C20:4 n6 ) was higher in the whole eggs of the older hens, which is in agreement with Cherian (2008). The share of docosahexaenoic acid (DHA, C22:6 n-3), another very important fatty acid for human health, was the lowest in the eggs of hens at the beginning of the experiment (46 weeks of age), after which its content increased and remained approximately the same until the end of the experiment.

Comparing our study with those presented in the literature, we found no papers presenting the fatty acid composition separately for morning and afternoon eggs. The interpretation of the results of the different trials is difficult because in every trial different ages of hens, different diets and housing systems were used. All examined eggs had a much higher n$6 / n-3$ ratio than the dietary recommended value of $10: 1$ or lower (suggested by Simopoulos, 2000), which is consistent with the majority of literature data.

Eggs of Naked Neck hens were located in the positive area of PC1, in which DM (dry matter), fat, ash, protein and total SFA showed the highest loadings, whereas eggs of Lohmann Brown hens were in the negative quarter, which means that they were inversely correlated to abovementioned parameters. Regarding PC2, which was mainly determined by PUFAs, Naked Neck eggs were mainly located on the negative side, while Lohmann Brown eggs had intermediate values. It can also be observed that the PCA did not manage to separate eggs collected at the beginning of the trial (A 46 weeks of age) and after 3 weeks (D - 49 weeks of age). However, eggs collected after 1 week (B - 47 weeks of age) were mainly located on the negative side of PC1 and of PC2, whereas eggs collected after 2 weeks $(\mathrm{C}-48$ weeks of age) were mainly located on the positive side of PC1 and of PC2, which indicates the opposite characteristics of these eggs.

The results obtained showed that eggs of commercial hens had significantly less fat, ash and protein and more water content (lower dry-matter content) compared to eggs from the autochthonous breed. Eggs of Naked Neck hens contained significantly more SFA and less PUFA compared to commercial ones, while the share of an egg's total n-3 fatty acids did not differ significantly between breeds. The Lohmann Brown eggs had higher levels of total n- 6 fatty acids, which led to a higher $n-6 / n-3$ ratio. The share of total MUFA significantly decreased, while the share of total PUFA, n-6 and the $n-6 / n-3$ ratio significantly increased with the age of hens. Additionally, compared to morning eggs, afternoon eggs had a significantly higher share of total n-6 fatty acids, which however, had no significant effect on the n-6/n-3 ratio. Finally, PCA offered a good separation according to hen breed and age when two first principal component were extracted. The most important variables were proximate composition and SFA content, with which PCA explained $50.97 \%$ of all differences between eggs. In conclusion, from a nutritional point of view, eggs from Lohmann Brown hens aged 48 and 49 weeks appeared to be healthier (less fat and higher total
PUFA content) and thus might, overall, be more acceptable to consumers.

Acknowledgements. This research was financed by the Ministry of Education, Science and Technological Development, Republic of Serbia (project TR-31033).

Edited by: K. Wimmers

Reviewed by: four anonymous referees

\section{References}

Anderson, K. E.: Comparison of fatty acid, cholesterol, and vitamin $\mathrm{A}$ and $\mathrm{E}$ composition in eggs from hens housed in conventional cage and range production facilities, Poult. Sci., 90, 1600-1608, 2011.

Aronson, W. J., Glaspy, J. A., Reddy, S. T., Reese, D., Heber, D., and Bagga, D.: Modulation of omega-3/omega- 6 polyunsaturated ratios with dietary fish oils in men with prostate cancer, Urology, 58, 283-288, 2001.

Ayerza, R. and Coates, W.: Dietary levels of Chia: Influence on yolk cholesterol, lipid content and fatty acid composition for two strains of hens, Poult. Sci., 79, 724-739, 2000.

Bean, L. D. and Leeson, S.: Long-term effects of feeding flaxseed on performance and egg fatty acid composition of brown and white hens, Poult. Sci., 82, 388-394, 2003.

Cherian, G.: Egg quality and yolk polyunsaturated fatty acid status in relation to broiler breeder hen age and dietary n-3 oils, Poult. Sci., 87, 1131-1137, 2008.

Cherian, G., Li, S. X., and Sim, J. S.: Dietary $\alpha$-linolenic acid and laying hen strain: Fatty acid of liver, adipose tissue, white meat, dark meat and egg yolk, J. Agr. Food Chem., 43, 2553-2559, 1995.

Edwards, H. M.: The influence of breed and/or strain on the fatty acid composition of egg lipids, Poult. Sci., 43, 751-754, 1964.

Farrell, D. J.: Enrichment of hen eggs with $\mathrm{n} 3$ long-chain fatty acids and evaluation of enriched eggs in humans. Am. J. Clin. Nutr., 68, 538-544, 1998.

Guardiola, F., Codony, R., Rafecas, M., Boatella, J., and Lopez, A.: Fatty acid composition and nutritional value of fresh eggs, from large and small scale farms, J. Food Compos. Anal., 7, 171-188, 1994.

Hammershøj, M.: Effects of dietary fish oil with natural content of carotenoids on fatty acid composition, n-3 fatty acid content, yolk colour and egg quality of hen eggs, Arch. Geflugelkd., 59, 189-197, 1995.

ISO 936: Meat and meat products - Determination of ash content, Switzerland: International Organization for Standardization, 1998.

ISO 937: Meat and meat products - Determination of nitrogen content Switzerland: International Organization for Standardization, 1978.

ISO 1442: Meat and meat products - Determination of moisture content, Switzerland: International Organization for Standardization, 1997.

ISO 1443: Meat and meat Products - Determination of total fat content, Switzerland: International Organization for Standardization, 1973. 
ISO 5509: Animal and vegetable fats and oils - Preparation of methyl esters of fatty acids, Switzerland: International Organisation for Standardisation, 2007.

Latour, M. A., Peebles, E. D., Doyle, S. M., Pansky, T., Smith, T. W., and Boyle, C. R.: Broiler breeder age and dietary fat influence the yolk fatty acid profiles of fresh eggs and newly hatched chicks, Poultry Sci., 77, 47-53, 1998.

Lin, L. Y. and Lee, M. H.: Effect of hen's age on the composition of yolk lipid, Food Sci. Taiwan, 23, 168-173, 1996.

Lopez-Bote, C. J., Sanz Arias, R., Rey, A. I., Castanõ, A., Isabel, B., and Thos, J.: Effect of free-range feeding on n-3 fatty acid anda-tocopherol content and oxidative stability of eggs, Anim. Feed Sci. Tech., 72, 33-40, 1998.

Milinsk, M. C., Murakami, A. E., Gomes, S. T. M., Matsushita, M., and de Souza, N. E.: Fatty acid profile of egg yolk lipids from hens fed diets rich in $\mathrm{n} 3$ fatty acids, Food Chem., 83, 287-292, 2003.

Milošević, N., Perić, L., Đukić-Stojčić, M., Trivunović, S., Rodić, V., and Bjedov, S.: Autochthonous hen breeds in the Republic of Serbia-Banat Naked Neck and Sombor Crested, World Poultry Sci. J. 69, 153-162, 2013.

Nielsen, H.: Hen age and fatty acid composition of egg yolk lipid, Brit. Poultry Sci., 39, 53-56, 1998.

Pavlovski, Z., Škrbić, Z., Lukić, M., Vitorović, D., and Petričević, V.: Naked Neck - autochthonous breed of chicken in Serbia: Carcass characteristics, Biotech. Anim. Husb., 25, 1-10, 2009.

Rakonjac, S., Bogosavljević-Bošković, S., Pavlovski, Z., Škrbić, Z., Dosković, V., Petrović, M. D., and Petričević, V.: Laying hen rearing systems: a review of chemical composition and hygienic conditions of eggs, World Poultry Sci. J., 70, 151-163, 2014.
Rizzi, C. and Chiericato, G. M.: Chemical composition of meat and egg yolk of hybrid and Italian breed hens reared using an organic production system, Poult. Sci., 89, 1239-1251, 2010.

Rodić, V., Perić, L., Pavlovski, Z., and Milošević, N.: Improving the poultry sector in Serbia: major economic constraints and opportunities, World Poultry Sci. J., 66, 241-250, 2010.

Scheideler, S. E., Jaroni, D., and Froning, G.: Strain and age effects on egg composition from hens fed diets rich in n-3 fatty acids, Poult. Sci., 77, 192-196, 1998.

Simopoulos, A. P.: Role of poultry products in enriching the human diet with n-3 PUFA. Human requirement for $n-3$ polyunsaturated fatty acids, Poult. Sci., 79, 961-970, 2000.

Škrbić, Z., Pavlovski, Z., Lukić, M., Krnjaja, V., Bijelić, Z., and Trenkovski, S.: [Rearing system and technology of production of broiler meat], Biotech. Anim. Husb. special issue, 6-81, 2010 [in Serbian].

SPSS: IBM SPSS Statistics 20. 1 New Orchard Road, Armonk, New York, United States: IBM Corporation, 2010.

Wesley Alexander, J.: Immunonutrition: The role of (omega)-3 fatty acids, Nutrition, 14, 627-633, 1998.

Yilmaz-Dikmen, B. and Sahan, U.: The relationship among age, yolk fatty acids content, and incubation results of broiler breeders, Poult. Sci., 88, 185-190, 2009. 